\title{
Lipopolysaccharide-Induced Human Enterocyte Tolerance to Cytokine-Mediated Interleukin-8 Production May Occur Independently of TLR-4/MD-2 Signaling
}

\author{
TOR C. SAVIDGE, PAUL G. NEWMAN, WEI-HUA PAN, MEI-QIAN WENG, HAI NING SHI, BETH A. MCCORMICK, \\ ANDREA QUARONI, AND W. ALLAN WALKER
}

\author{
Developmental Gastroenterology Laboratory [T.C.S., P.G.N., W.-H.P., M.-Q.W., H.N.S., B.A.M., WAW.], MA General Hospital and \\ Harvard Medical School, Charlestown, MA 02129; Section of Physiology [A.Q.], Cornell University, Ithaca, NY 14853
}

\begin{abstract}
Intestinal epithelial cells (IEC) are constantly exposed to bacterial components, such as LPS, without triggering proinflammatory immune responses. This study demonstrates that chronic exposure of human-derived IEC to LPS induces tolerance to an endogenous inflammatory cytokine (IL- $1 \beta$ ) activated IL- 8 response that occurs independently of TLR-4/MD-2 signaling. IL-8 production in response to activation by unrelated TNF- $\alpha$ and PMA signaling pathways is also inhibited, indicating a broad-spanning tolerance. Quantitative rtPCR and IL-8 promoter-luciferase assays demonstrate that tolerance is regulated at the transcriptional level and occurs independently of IEC cytodifferentiation. By contrast, LPS does not significantly alter other proinflammatory signaling cascades in IEC that function independently of IL-8 production, e.g., IL-6 secretion and PEEC (Hepoxilin A3)-induced neutrophil transepithelial migration in response to invasive Salmonella typhimurium. Human IEC have therefore developed LPS-induced signaling cascades that promote an IL-8 hyporesponsiveness to proinflammatory cytokines while LPS exposure does not compromise the ability of IEC to mount other proinflammatory immune responses to invasive enteropathogens. (Pediatr Res 59: 89-95, 2006)
\end{abstract}

$\mathrm{T}^{\mathrm{s}}$ The gastrointestinal (GI) tract performs several important nutritional and secretory functions in a complex microenvironment where intestinal epithelial cells (IEC) are constantly exposed to commensal bacteria and food antigens on the luminal interface and locally secreted cytokine products on the basolateral domain. As a consequence, IEC have evolved to provide a mechanical barrier function that allows appropriate processing of ingested food components, while tolerating microbial components that may trigger intestinal inflammation. For example, endotoxin or lipopolysaccharide (LPS) is a common glycolipid cell wall component of Gram-negative bacteria and is a potent activator of immune responses in macrophages and monocytes, yet IEC are normally hyporesponsive to extracellular LPS (1-3).

Received January 24, 2005; accepted June 21, 2005

Correspondence: W. Allan Walker, M.D., Developmental Gastroenterology Laboratory, Combined Program in Pediatric Gastroenterology and Nutrition, MA General Hospital and Harvard Medical School, $11416^{\text {th }}$ Street, Charlestown, MA 02129; e-mail: wwalkerpartners.org

This study is supported by grants from the Crohn's and Colitis Foundation and the National Institutes of Health (RO1 DK70260; R37 HD12437; PO1 DK33506; P30 DK40561)
A category of pattern-recognition receptors termed Tolllike receptors (TLRs) in mammalian cells provide the necessary signaling pathways that trigger innate proinflammatory immune responses to various bacterial components (4). Ligand recognition of LPS is principally mediated via TLR-4, which is characterized by extracellular leucine-rich-repeats and a cytoplasmic domain that imparts functional similarity to the IL-1 receptor. LPS-mediated activation of NF $\kappa$ B transcriptional activity and proinflammatory cytokine production requires a coordinated interaction of LPS-binding protein, CD14, TLR-4 and secreted MD-2. Diminished TLR-4 expression and a lack of the MD-2 gene product in human IEC are thought to be the primary mechanisms that impart a hyporesponsiveness to extracellular LPS under normal conditions $(2,3)$.

In this study, we report that IL-8 production by human IEC is significantly suppressed following an LPS-induced crosstolerance to IL- $1 \beta$, TNF- $\alpha$ and PMA activation. We additionally demonstrate that this tolerance operates in the absence of a functional TLR-4/MD-2 signaling complex. IL-6 secretion and proinflammatory signaling cascades, triggered by invasive enteropathogens such as Salmonella typhimurium, are not similarly suppressed following LPS exposure of IEC. Thus, commensal gut bacteria may impart a novel form of hyporesponsiveness by IEC to locally-acting cytokines that might otherwise promote IL-8 secretion, intestinal inflammation and cell death.

\section{MATERIALS AND METHODS}

Reagents and cell cultures. All reagents were obtained from Sigma Chemical Co. (St. Louis, MO) or GIBCO (Grand Island, NY) unless otherwise stated. Human-derived IEC lines used included: Caco-2, T84, HT-29, H4 and temperature-sensitive fetal human intestinal epithelial cells (tsFHI). Adult colonic adenocarcinoma cell lines (Caco-2, T84 and HT29) were cultured in 96 well tissue culture plates at $37^{\circ} \mathrm{C}$ in a $5 \% \mathrm{CO}_{2}$ atmosphere in Dulbecco's

Abbreviations: DPPIV, dipeptidylpeptidase IV; fMLP, n-formylmethionyl leucyl phenylalanine; GI, gastrointestinal; IEC, intestinal epithelial cell; IRAK, IL-1R-associated kinase; LTA, lipoteichoic acid; PEEC, pathogenelicited epithelial chemosattractant; PMN, polymorphonucleocyte; TLR, tolllike receptor; tsFHI, temperature sensitive fetal human intestinal epithelial cells

DOI: 10.1203/01.pdr.0000195101.74184.e3 
Modified Eagle Media (DMEM) with 10\% heat-inactivated FCS (FCS), 50 $\mathrm{U} / \mathrm{mL}$ penicillin and $50 \mu \mathrm{g} / \mathrm{mL}$ streptomycin. Fetal small intestinal nontransformed IEC (H4 and tsFHI) were cultured as described previously (5). tsFHI cells are transformed with a temperature sensitive simian virus 40 (SV40) large tumor antigen that allows cells to proliferate at $32^{\circ} \mathrm{C}$ but differentiate at $37-39^{\circ} \mathrm{C}$ due to the heat-labile nature of the SV40 T antigen (6). At $32^{\circ} \mathrm{C}$ tsFHI cells were cultured in optiMEM I supplemented with $4 \%$ FBS, 10 $\mathrm{ng} / \mathrm{mL}$ EGF, $2 \mathrm{mM}$ glutamine, $2 \mathrm{mM}$ L-alanyl-glutamine (GlutaMAX I) and $10 \mathrm{mM}$ HEPES. Differentiated tsFHI cells were grown at $37^{\circ} \mathrm{C}$ for $7 \mathrm{~d}$ in DMEM supplemented with 7\% FCS, 2 mM glutamine, 2 mM GlutaMAX I and $10 \mathrm{mM}$ HEPES. Human monocytic THP-1 cells were cultured in RPMI medium with $10 \%$ heat-inactivated FCS. Cell viability was assessed using the terazolium salt 3-[4,5-Dimethylthyazol-2-y]-2,5-diphenyltetrazolium bromide (MTT) cytotoxicity assay.

Commercial LPS was prepared from Escherichia coli 055:B5 or purified protein-free Salmonella minnesota R595 (List Biologic Labs, Campbell, CA). To neutralize the effects of LPS on cells, agarose-bound polymyxin B (40 $\mu \mathrm{L} / \mathrm{mL}$ ) was added to media containing $100 \mathrm{ng} / \mathrm{mL}$ LPS $\left(3 \mathrm{~h}\right.$ at $4^{\circ} \mathrm{C}$ ) before addition. Neutralizing mouse anti-human TLR2.1 and TLR4 antibodies (20 $\mu \mathrm{g} / \mathrm{mL}$ ) and $\mathrm{IgG}_{2 \mathrm{a}}$ isotype control were purchased from eBioscience (San Diego, CA). Purified Clostridium difficile toxin A was kindly provided by $\mathrm{Dr}$ Charalabos Pothoulakis (Beth Israel Deaconess Medical Center, Boston).

Intracellular $\mathbf{c A M P}(\boldsymbol{c A M P})$ assay. Intracellular cAMP mobilization to 10 $\mathrm{ng} / \mathrm{mL}$ forskolin stimulation was measured in LPS treated cells using an enzyme-immunoassay as described by the manufacturer (AmershamPharmacia- Biotech, Piscataway, NJ).

Neutrophil transepithelial migration assay. T84 IEC monolayers were seeded on collagen-coated filters for $7 \mathrm{~d}$. To assess the polarity and integrity of the monolayers, transepithelial resistances were measured using a voltometer (EVOM, World Precision Instruments). S. typhimurium SL1344 were added to the apical chamber of T84 IEC monolayers grown on collagencoated filters (incubated in HBSS at a multiplicity of infection ratio of 375:1). After $1 \mathrm{~h}$, nonadherent bacteria were washed away and freshly isolated human polymorphonucleocyte $(\mathrm{PMN})\left(1 \times 10^{6}\right)$ were added to the basolateral chamber of the inverted monolayers for $2 \mathrm{~h}$ as described previously (7). Transmigration of PMN was assayed by measuring myeloperoxidase (MPO) activity in the apical supernatant. Addition of chemoattractant $(1 \mu \mathrm{M} \mathrm{n}$ formylmethionyl leucyl phenylalanine, fMLP) to the apical chamber was used as a positive control for PMN transmigration. Negative controls were provided by a noninvasive $S$. typhimurium W341 strain.

Real-time quantitative PCR (rt-PCR). Total RNA was extracted from frozen tissues, treated with $1 \mathrm{U}$ DNAse I and reverse transcribed (Gene Amp RNA-PCR Kit). Real-time PCR was performed using SYBR Green PCR Master-Mix for 40 cycles on an Opticon II DNA engine (MJ Research, Inc.) $\left(94^{\circ} \mathrm{C}\right.$ for $2 \mathrm{~min} ; 94^{\circ} \mathrm{C}$ for $1 \mathrm{~min} ; 60^{\circ} \mathrm{C}$ for $1 \mathrm{~min} ; 72^{\circ} \mathrm{C}$ for $1 \mathrm{~min}$; repeat step 2-to-4 for 40 cycles; $72^{\circ} \mathrm{C}$ for $10 \mathrm{~min}$ ). Primer sets for IL-8: Forward 5'-GCCGTGGCTCTCTTGGC-3'; Reverse 5'-GCACTCCTTGGCAAAACTGC-3' and GAPDH: Forward 5'-GAGTCAACGGATTTGGTCGTAT-3'; Reverse 5'-AGTCTTCTGGGTGGCAGTGAT-3'. Quantification of TLR2 (Forward 5' - ATGGCCTGTGGTATATGAAAATGA-3'; Reverse 5' GGGCCACTCCAGGTAGGTCTT-3'), TLR4 (Forward 5'-CCTCCCCTGTACCCTTCTCACTG-3'; Reverse 5'-ACGGCTACACCATTTTCCATTCC-3'), DPPIV (Forward 5'-GGTCTGCCCCTCTATACTCTACAC-3'; Reverse 5'-TGGGCCTGCATACACATCTAATA-3') and human glucose-6phosphate dehydrogenase (Forward 5' -CCCGCCCCTCGCTGCTGCTAC-3'; Reverse 5'-ATGGGCGCCCTCCTCCTTCCTTCT-3') was performed using PCR-generated dsDNA standards produced with the same primers. Reference DNAs were purified on agarose gels and quantified spectrophotometrically. LightCycler Relative Quantification Software was used to normalize data to the standard Glucose-6-phosphate Dehydrogenase mRNA level. Reactions were set up using QuantiTect SYBR Green RT-PCR kit reagents (Qiagen) following the included instructions. Two-to-five samples were run for each total RNA, and each reaction contained $0.5 \mu \mathrm{g}$ total RNA.

Human IL-8 promoter reporter assays and ELISA. IL-8 promoter reporter assays were performed by transient transfection using a firefly luciferase construct containing 1521 bp (1481 to +40$)$ of the human IL-8 gene as described previously (8). Briefly, transfection of IEC was accomplished using Lipofectamine 2000 as specified by the manufacturers instructions (Life Technologies, Rockville, M.D.). Cells were grown to $75 \%$ confluence and incubated with Lipofectamine 2000 reagent plus an IL-8 promoter-dependent firefly luciferase reporter construct (wild type and mutant constructs for IL-8 promoter sites $\mathrm{NF} \kappa \mathrm{B}, \mathrm{C} / \mathrm{EBP}$ and $\mathrm{AP}-1)$, and a constitutively-expressed Renilla luciferase reporter as an internal control for transfection efficiency. After $40 \mathrm{~h}$, cells were stimulated with $50 \mathrm{ng} / \mathrm{mL} \mathrm{IL}-1 \beta$ for $3 \mathrm{~h}$. Cells were then lysed and the Dual-Luciferase Reporter Assay (Promega) was carried out using a luminometer. Firefly luciferase activity values were normalized to
Renilla luminescence, and luminescence ratios normalized to obtain a value of fold-increase in luminescence over control.

IL-8 secretion was measured in tissue culture supernatants by ELISA as described previously, (5) or in IEC cell lysates [100 mM HEPES [pH 7.4],

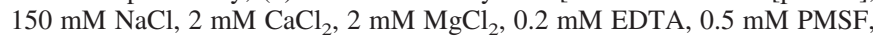
$50 \mathrm{mM} \mathrm{NaF}, 1 \mathrm{mM} \mathrm{NaVO}_{4}, 0.1 \%$ trixton X-100]. Ninety-six-well microtiter plates (Immulon 2HB) were coated overnight with anti-human IL-8 (R\&D systems), and then incubated overnight at $4^{\circ} \mathrm{C}$ with $50 \mu \mathrm{L}$ of cell culture supernatant. After sequential incubations with rabbit anti-human IL-8 (Endogen), horseradish peroxidase (HRP)-conjugated goat anti-rabbit IgG (Biosource) and TMB substrate, the absorbance was measured at $450 \mathrm{~nm}$ using a microplate reader. IL-8 values were normalized to total cellular protein as determined with the Bio-Rad DC Protein assay (Bio-Rad) following the manufacturer's instructions. IL-6 secretion by IEC was measured in cell culture supernatants using a commercial Quantikine human IL-6 kit as recommended by the manufacturer (R \& D Systems).

Statistical analysis. Results are presented as mean values \pm SEM. Statistical significance was determined using $t$ test or Mann-Whitney U test for Ranks. $n=3$ unless otherwise stated; $p<0.05$ was considered statistically significant.

\section{RESULTS}

Human IEC are hyporesponsive to extracellular LPS. Human IEC have been shown to express TLR-4, although some discrepancy exists in the literature as to whether the levels of TLR-4 and MD-2 expression are sufficient to allow human IEC to respond to LPS challenge $(1-3,15-20)$. We used 5 different human-derived IEC cell lines to examine whether these cells produced IL-8 in response to LPS stimulation. Cells included established transformed adenocarcinoma cell lines (Caco-2, T84 and HT-29), and nontransformed primary human fetal small intestinal IEC (H4 and tsFHI, a conditionally-transformed cell line expressing the temperature-sensitive SV40-large T antigen). tsFHI cells proliferate at $32^{\circ} \mathrm{C}$ but enter cell-cycle arrest and differentiate when incubated at $37-39^{\circ} \mathrm{C}$ due to the heat-labile nature of the T-antigen expression. For all cell lines tested, repeated attempts failed to demonstrate a significant IL-8 response to LPS stimulation, even with concentrations up to $100 \mu \mathrm{g}$ LPS $/ \mathrm{mL}$ (Figure 1A). Our findings therefore support the notion that human IEC are hyporesponsive to extracellular LPS $(1-3,19,20)$.

LPS-mediated tolerance to IL-1 $\beta$ signaling in human IEC. We next examined whether LPS, although unable to directly stimulate IL-8 secretion, exerted tolerance to IL-1 receptor-mediated signaling. We demonstrated that all cell lines tested, except HT29 cells, produced IL-8 in response to IL- $1 \beta$ activation (Figure 1B). To allow for a direct comparison between the different cell lines, IL- 8 concentrations were normalized to cell protein content. Protein concentrations were comparable for all wells in each given cell line, ruling out an alteration in overall protein synthesis as an explanation for differences in IL- $1 \beta$ stimulation. A notable finding was that the nontransformed fetal-derived $\mathrm{H} 4$ and tsFHI cell lines were more responsive to IL- $1 \beta$ than the adult transformed cells.

In the human GI tract, IEC are constantly exposed to commensal bacteria and LPS for approximately two days as they migrate out of the segregated crypt microenvironment where the cells proliferate (21). Consequently, to recapitulate this chronic endotoxin exposure we incubated IEC with varying concentrations of E. coli derived LPS for different times up to $2 \mathrm{~d}$ and then examined the effect on IL-1 receptor- 

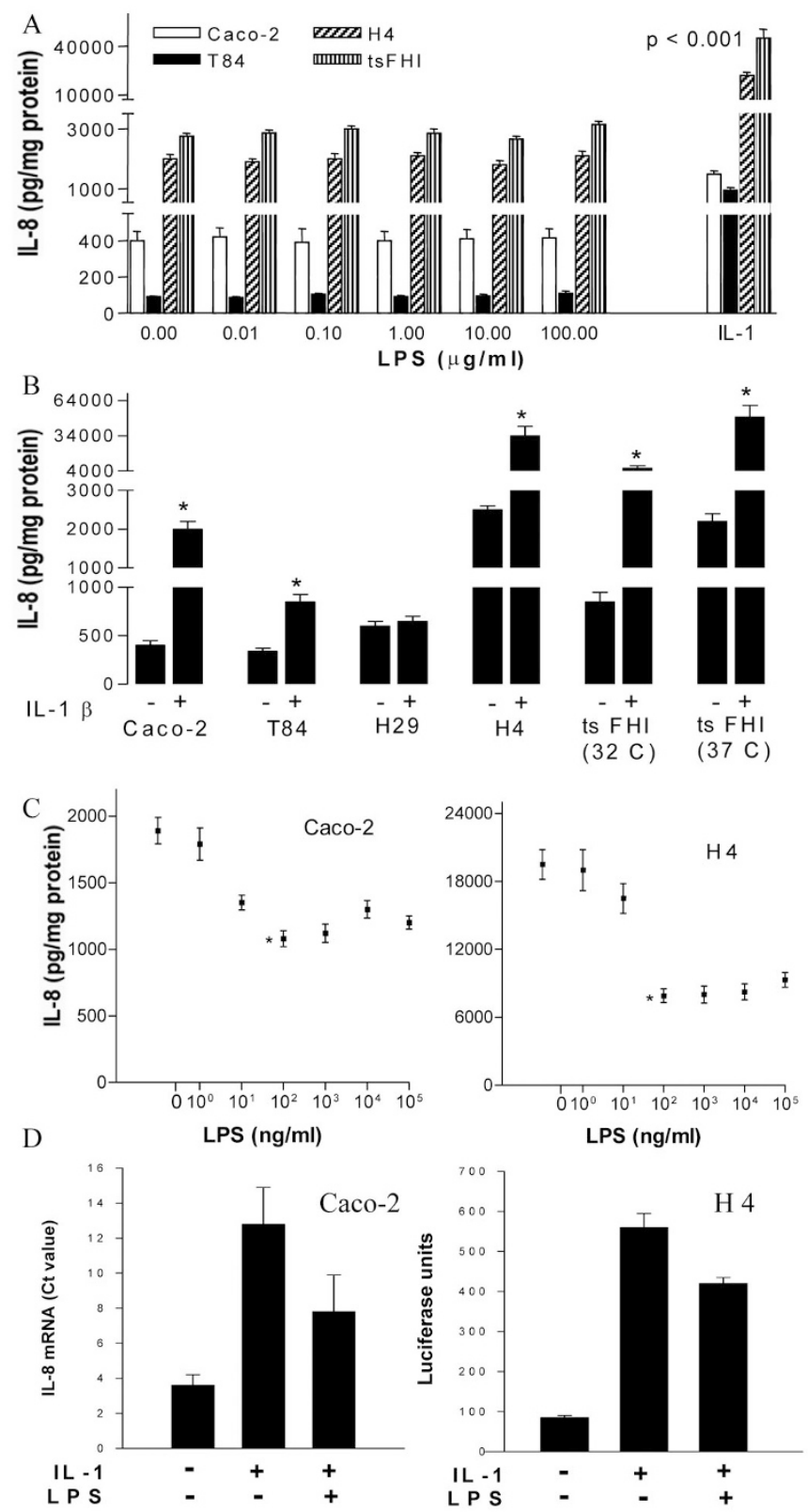

Figure 1. LPS induced tolerance of IL- $1 \beta$ activated IL-8 secretion in human IEC. (A). IL-1 $\beta(50 \mathrm{ng} / \mathrm{mL})$ effects on IL-8 secretion in 4 different IEC lines after $24 \mathrm{~h}\left(\log _{10}\right.$; corrected for protein concentration). (B). IL- $1 \beta$ effects were compared in transformed tsFHI (at $32^{\circ} \mathrm{C}$ ) and nontransformed tsFHI cells grown at $37^{\circ} \mathrm{C}$ for $1 \mathrm{wk}(* p<0.01)$. $(C)$ Dose-dependent LPS-mediated $(E$. coli derived; for $48 \mathrm{~h})$ inhibition of IL- $1 \beta(50 \mathrm{ng} / \mathrm{mL}$ for $24 \mathrm{~h})$ activated IL-8 secretion in Caco-2 and $\mathrm{H}-4$ cells $(* p<0.05)$. (D) Purified, protein free LPS-mediated (S. minnesota derived; $100 \mathrm{ng} / \mathrm{mL}$ for $48 \mathrm{~h}$ ) inhibition of IL-1 $\beta$ activated IL-8 secretion in Caco-2 and $\mathrm{H} 4$ cells. Addition of polymixin $\mathrm{B}$ (PB; $40 \mu \mathrm{L} / \mathrm{mL}$ ) to media $3 \mathrm{~h}$ before adding to cells ablated LPS induced tolerance $(n=2 ; * p<0.05)$.

mediated signaling. A dose-dependent LPS-mediated tolerance to IL- $1 \beta$ induced IL- 8 production was recorded (although to varying degrees) in all IEC lines tested (Figure 1C). Significant inhibition of IL-8 secretion was observed with LPS concentrations as low as $10 \mathrm{ng} / \mathrm{mL}$, with maximal inhibition observed at $100 \mathrm{ng} / \mathrm{mL}$.

To exclude the possibility that contaminants present in the LPS preparation, e.g., lipoteichoic acid (LTA), possibly me- diating the tolerance, we demonstrated a similar suppression in IL- $1 \beta$ stimulated IL- 8 production after IEC were pretreated with a highly purified, protein-free LPS (Fig. 1D). Additionally, tolerance was ablated by the prior addition of polymyxin $\mathrm{B}(\mathrm{PB})$ to neutralize LPS-mediated effects (Fig. 1D). Preexposure of cells to LPS was a prerequisite step in the induction of tolerance as simultaneous stimulation of IEC with LPS and IL-1 $\beta$ did not inhibit IL-8 production (data not shown).

LPS-induced suppression of IL-8 production in human IEC is not due to cell cytotoxicity and is regulated at the transcriptional level. To exclude the possibility that the suppressed IL-8 responses were caused by chronic cytotoxic effects of LPS on IEC, studies were conducted to assess cell viability and other unrelated signaling pathways in these cells. To determine in vitro cytotoxic effects on adherent IEC, the tetrazolium salt 3-[4,5-Dimethylthyazol-2-y]-2,5-diphenyltetrazolium bromide (MTT) viability assay was used to measure mitochondrial dehydrogenase enzyme activity in IEC. MTT assays and measurement of transepithelial electric resistance demonstrated that LPS incubation had no significant effect on IEC viability (Table 1). We next examined whether LPS exposure of IEC significantly suppressed other unrelated signaling pathways that occur independently of IL-8 production. Intracellular cAMP responses to forskolin $(10 \mathrm{ng} / \mathrm{mL})$ were unaffected by chronic LPS exposure (Table 1).

Quantitative real-time rtPCR analysis of total RNA and use of IL-8 promoter-luciferase reporter gene assays demonstrated that IL- $1 \beta$ induced IL- 8 gene expression was significantly inhibited following prior exposure of IEC to LPS (Fig. 2A). This pattern of gene expression correlated well with secreted (Fig. 1D) and intracellular levels of IL-8 accumulation (Fig. $2 B$ ), thereby indicating that LPS-mediated tolerance of IL-8 secretion in IEC is primarily regulated at the transcriptional level.

LPS-mediated suppression of IL-8 production is not influenced by IEC cytodifferentiation and is not restricted to $I L-1 \beta$ stimulation. A previous study has demonstrated that IL- $1 \beta$ stimulated IL-8 production in HT-29 cells is dependent on the cellular differentiation of these IEC (18). We therefore examined whether LPS-mediated tolerance of IL- $1 \beta$ activated

Table 1. Effect of chonic LPS exposure on IEC viability, TER, and intracellular cAMP responses

\begin{tabular}{lccc}
\hline & MTT (O.D.) & TER $\left(\mathrm{cm}^{-2}\right)$ & cAMP (fmol) \\
\hline Caco-2 & $1.15 \pm 0.05$ & $233 \pm 11$ & $3472 \pm 381$ \\
Caco-2 + LPS & $1.10 \pm 0.09$ & $216 \pm 23$ & $3622 \pm 410$ \\
Caco-2 + tox A & $0.09 \pm 0.03^{*}$ & $6 \pm 4^{*}$ & N.D. \\
H4 & $0.45 \pm 0.04$ & N.D. & $392.7 \pm 18.6$ \\
H4 + LPS & $0.41 \pm 0.08$ & N.D. & $419.8 \pm 28.7$ \\
H4 + tox A & $0.07 \pm 0.03^{*}$ & N.D. & N.D. \\
T84 & N.D. & $7658 \pm 468$ & N.D. \\
T84 + LPS & N.D. & $7156 \pm 513$ & N.D. \\
T84 + tox A & N.D. & $36 \pm 15^{*}$ & N.D. \\
\hline
\end{tabular}

Following IEC pretreatment with LPS $(100 \mathrm{ng} / \mathrm{ml}$ for $48 \mathrm{hr}$; S. minnesota derived), no significant differences were recorded in cell viability (MTT assay), transepithelial resistance (TER) and intracellular cAMP responses to $10 \mathrm{ng} / \mathrm{ml}$ forskolin for $10 \mathrm{~min}$. Significant effects were recorded in IEC treated with Clostridium difficile toxin A (toxA; 40nM) for 48 hours $\left({ }^{*} p<0.01, n=\right.$ $3)$. 

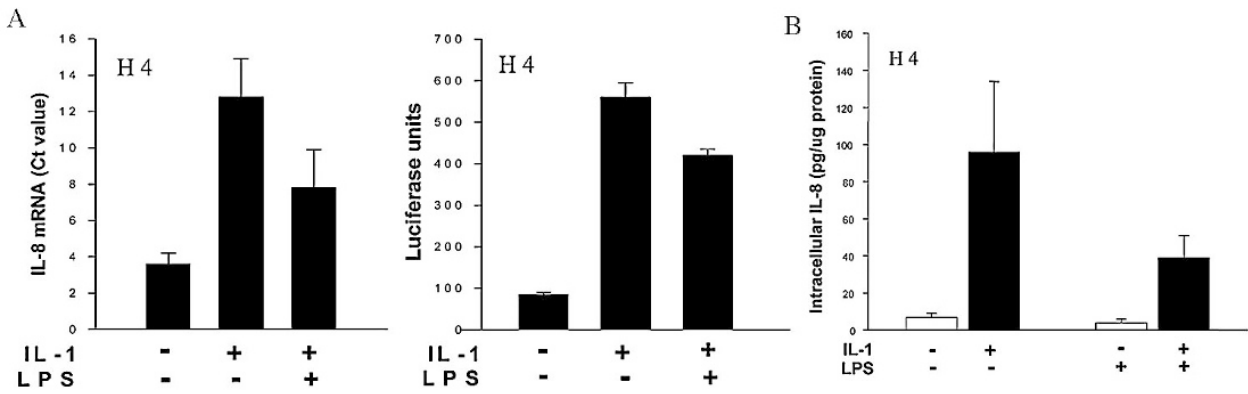

Figure 2. Representative graphs of quantitative real-time rtPCR showing IL-8 mRNA $(A)$ and intracellular IL-8 protein $(B)$ accumulation in H4 cells after a $2 \mathrm{~h}$ IL-1 $\beta$ stimulation $(50 \mathrm{ng} / \mathrm{mL})$, with and without purified LPS (100 ng/mL; S. minnesota derived for $48 \mathrm{~h} ; p<0.05, n=3$; Mann-Whitney U-test) (left panel); and a 3 h IL-8 luciferase promoter assay performed under similar conditions in Caco2 cells (right panel; arbitrary fluorescent units).

IL-8 production in IEC is due to changes in cellular differentiation induced by chronic LPS exposure. Quantitative realtime rtPCR analysis of the gene expression for the differentiation-dependent brush border enzyme dipeptidylpeptidase IV (DPPIV) demonstrated that LPS incubation of IEC did not induce cellular differentiation in IEC (Table 2). Therefore, LPS-mediated tolerance does not appear to occur as a consequence of cellular differentiation. This is supported further by the observation that $\mathrm{H} 4$ cells fail to differentiate when cultured on plastic (unpublished findings).

We next examined whether LPS-mediated tolerance was restricted to IL- $1 \beta$ activation of IEC, as has been suggested for IL-6 production in murine $\mathrm{m}-\mathrm{IC}_{\mathrm{c} 2}$ cells (14). By contrast, IL-8 secretion following TNF- $\alpha$ (Fig. 3A) and PMA (Fig. 3B) stimulation of IEC was also significantly suppressed after preincubating cells with $100 \mathrm{ng} / \mathrm{mL}$ LPS for $48 \mathrm{~h}$. LPSmediated tolerance is therefore not only restricted to IL- $1 \beta$ stimulation of human IEC but it also suppresses TNF- $\alpha$ and PMA-induced IL-8 production.

LPS-induced tolerance is not mediated via the TLR-4/ MD-2 signaling complex. We next examined whether LPS activated tolerance of IL-8 secretion in IEC is mediated via the TLR-4/MD-2 signaling complex pathway. Quantitative realtime PCR analysis of total RNA isolated from the human IEC cell lines demonstrated low transcript levels of TLR2 and TLR4 receptor expression in Caco-2 (Table 2) and tsFHI cells (data not shown), compared with LPS-responsive THP-1 cells (Table 2). H4 cells displayed no significant quantities of TLR-2 or TLR-4 receptor expression by quantitative rtPCR (Table 2), or by western-blot analysis/immunofluorescence

Table 2. Quantitative real-time PCR determination of DPPIV and TLR gene expression

\begin{tabular}{lccc}
\hline & DPPIV & TLR-2 & TLR-4 \\
\hline Caco-2 & 20450 & 913 & 2048 \\
Caco-2 + LPS & 18450 & 352 & 3505 \\
H4 & $<1$ & $<1$ & $<1$ \\
H4 + LPS & $<1$ & $<1$ & $<1$ \\
THP-1 & $<1$ & 4393 & 28760 \\
\hline
\end{tabular}

Median values of gene transcript numbers for the IEC cytodifferentiation marker DPPIV, and TLR-2 and TLR-4 from $0.5 \mu \mathrm{g}$ total RNA using PCR-generated reference DNA's. LightCycler Relative Quantification Software was used to normalize data to the same Glucose-6-phosphate Dehydrogenase (G6PD) mRNA level. In H4 cells, expression of DPPIV, TLR-2 and TLR-4 was below 1 copy/0.5 $\mu \mathrm{g}$ total RNA, whereas G6PD copies for control and LPS treated cells were 12570 and 18 220, respectively.

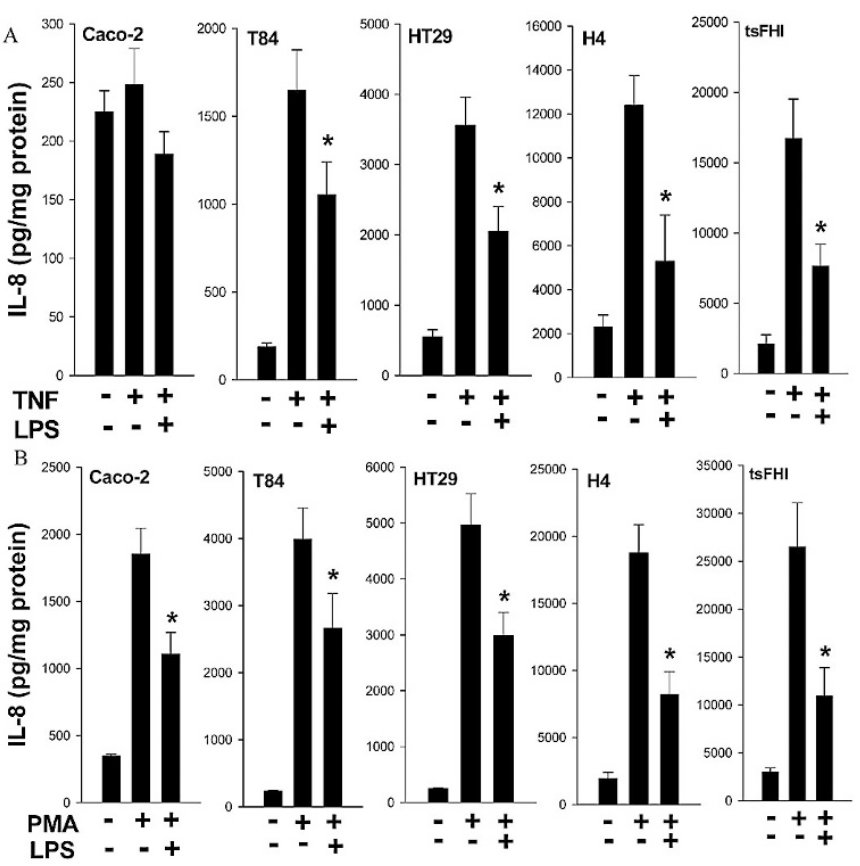

Figure 3. LPS-mediated tolerance of $\mathrm{TNF} \alpha$ and PMA stimulated IL- 8 secretion in human IEC. (A) LPS-induced ( $100 \mathrm{ng} / \mathrm{mL}$ for $48 \mathrm{~h} ; S$. minnesota derived) suppression of TNF $\alpha(50 \mathrm{ng} / \mathrm{mL})$ treated human IEC lines $(24 \mathrm{~h}$ stimulation; *, $p<0.05, n=3$ ). (B) LPS-induced suppression of PMA (100 $\mathrm{ng} / \mathrm{mL}$ ) treated human IEC lines.

(data not shown). In addition, using rtPCR analysis we failed to demonstrate MD-2 expression in any of the IEC cell lines tested (data not shown), which is in agreement with previous work describing an aberrant TLR-4/MD-2 function in human $\operatorname{IEC}(2,3)$.

To further examine whether the induction of LPS-mediated tolerance in IEC involved alterations in the signaling pathway of NF $\kappa \mathrm{B}$ activation, $\mathrm{H} 4$ cells were treated with or without LPS and then exposed to IL-1 $\beta$. Immunoblot analysis showed that LPS-pretreatment resulted in a decrease in $\mathrm{I} \kappa \mathrm{B} \alpha$ degradation (Fig. 4A). By contrast, all of the IEC cell lines (expect HT29 cells) were highly responsive to IL-1 $\beta$ activation (Fig. 1 and Fig. 4A), indicating that intracellular signaling cascades shared between upstream IL- $\beta$ and TLR-4 receptors to downstream $\mathrm{NF} \kappa \mathrm{B}$-mediated transcriptional activation of the IL-8 gene remain intact. Furthermore, preincubation of IEC with neutralizing MAb (MAb's) to TLR-4 and TLR-2 dem- 

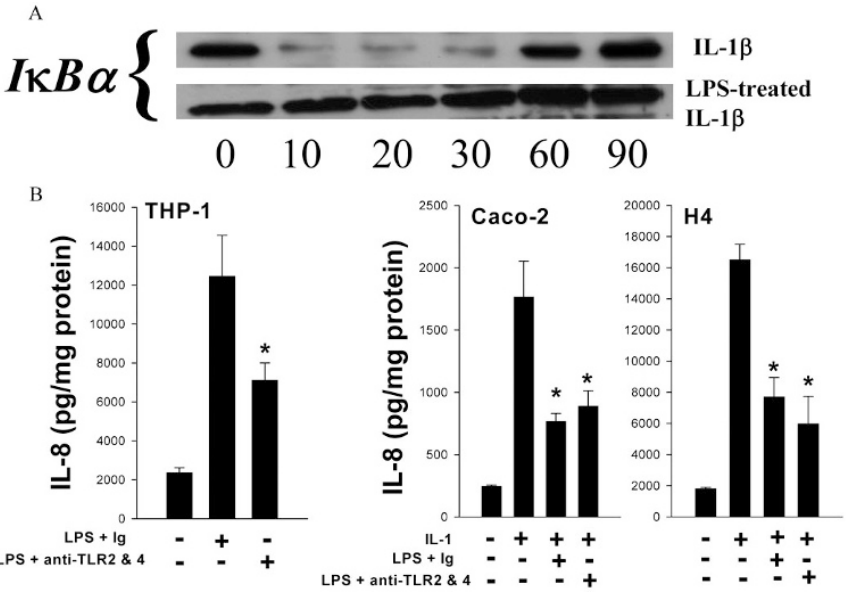

Figure 4. LPS pretreatment results in a decrease in IL- $1 \beta$-induced $\mathrm{I} \kappa \mathrm{B} \alpha$ degradation. (A) H4 cells with or without treatment with LPS were subsequently treated with IL- $1 \beta$ for indicated time. I $\kappa \mathrm{B} \alpha$ degradation was examined by immunoblot ( $\mathrm{I} \kappa \mathrm{B} \alpha \mathrm{sc}-847$, Santa Cruz Biotechnology). The temporal effects $(0,10,20,30,60,90 \mathrm{~min})$ of IL-1 $\beta(50 \mathrm{ng} / \mathrm{mL})$ and LPS $(10 \mu \mathrm{g} / \mathrm{mL})$ on $\mathrm{I} \kappa \mathrm{B} \alpha$ degradation were detected. (B) LPS $(10 \mathrm{ng} / \mathrm{mL} ; S$. minnesota derived) effects on IL-8 secretion in THP- 1 cells after $24 \mathrm{~h}$ with isotype $\mathrm{IgG}_{2 \mathrm{a}}$ control or blocking anti-TLR 2 and TLR-4 MAb's $(20 \mu \mathrm{g} / \mathrm{mL} ; n=2$; * $p<$ 0.01) (left panel). Right panel demonstrates that blocking with anti-TLR-2 and TLR-4 MAb's does not have a significant effect on LPS-mediated (100 $\mathrm{ng} / \mathrm{mL}$ for $48 \mathrm{~h}$; $S$. minnesota derived) inhibition of IL-8 secretion following stimulation with IL-1 $\beta(50 \mathrm{ng} / \mathrm{mL})$ for $24 \mathrm{~h}(n=3, * p<0.01)$.

onstrated that these receptors were not involved in the initiation of tolerance (Figure 4B).

LPS-mediated tolerance is specific to IL-8 secretion in human IEC as it does not significantly alter other proinflammatory pathways. We next examined whether other unrelated proinflammatory pathways in human IEC were also significantly suppressed by chronic LPS exposure. These studies demonstrated that IL-6 secretion (Fig. 5A), and pathogenelicited epithelial chemosattractant (PEEC, the eicosanoid hepoxilin A3)-mediated transepithelial migration of human PMN following bacterial invasion of IEC (22) (Fig. 5B) were
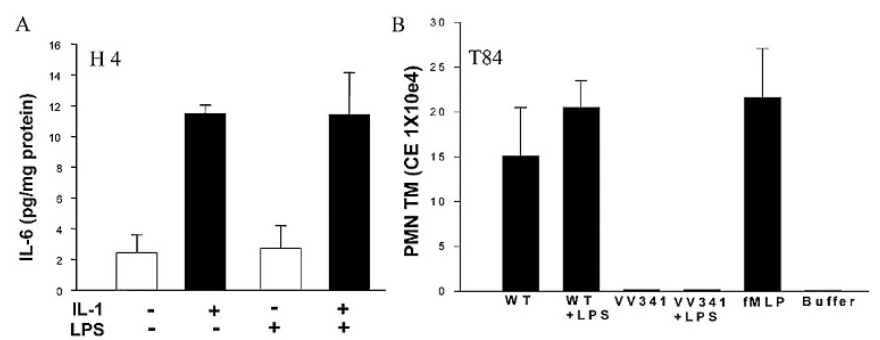

Figure 5. LPS-mediated effects on IL-6 secretion and hepoxilin A3-induced PMN transepithelial migration in IEC. (A). Purified, protein free LPSmediated (S. minnesota derived; $100 \mathrm{ng} / \mathrm{mL}$ for $48 \mathrm{~h}$ ) inhibition of IL-1 $\beta$ activated IL- 6 secretion in $\mathrm{H} 4$ cells. IL- $1 \beta$ induces a significant increase in IL-6 secretion ( $p<0.05$; Mann-Whitney U-test), but no significant difference was recorded between LPS-treated and control cell cultures. (B) Salmonella typhimurium-induced PMN transmigration. LPS pretreatment (S. Minnesotaderived $(100 \mathrm{ng} / \mathrm{mL})$ added to apical and basolateral chambers for $48 \mathrm{~h}$ ) of T84 cells did not show a significant difference in the ability that invasive $S$. typhimurium (WT) have in inducing PMN transmigration into the apical tissue culture chamber. A noninvasive S. typhimurium VV341 (hilA mutant) served as a negative control, which demonstrated that LPS pretreatment did not by itself induce PMN transmigration $(p<0.01, n=3)$. fMLP $(1 \mu \mathrm{M})$ served as a positive control. unaltered. In the latter experiment, confluent T84 cells exposed to $100 \mathrm{ng} / \mathrm{mL}$ LPS for $48 \mathrm{~h}$ demonstrated no significant difference in their ability to recruit PMN following exposure to invasive Salmonella typhimurium SL1344 (7). Chronic exposure of IEC to LPS therefore appears to specifically suppress IL-8 responses to pro-inflammatory stimuli while distinct pro-inflammatory responses unrelated to IL-8 signaling remain intact.

\section{DISCUSSION}

LPS-mediated tolerance is a well-established phenomenon that has been described in a number of different experimental systems (9-14). Recent studies have demonstrated the induction of cross-tolerance in macrophages by ligands using different TLR's, (23-25) and by over-expression of TLR's in Chinese hamster ovary cells (26). This tolerance is not limited to TLR-4 agonists, but also affects signaling pathways associated with ligands of other TLR family members. For example, preexposure of macrophages to LPS confers a subsequent hyporesponsiveness to repeat endotoxin challenge, as well as inducing a cross-tolerance to other bacterial components, such as lipoteichoic acid (LTA) (9-12). Similarly, LTA induces a cross-tolerance to a subsequent LPS challenge indicating that distinct TLR-2 and TLR-4 receptor pathways may be indirectly suppressed, possibly by modulating IL-1 receptorassociated kinase activity (13). LPS-induced tolerance to LPS re-exposure has also been demonstrated in the murine $\mathrm{m}-\mathrm{IC}_{\mathrm{cl} 2}$ IEC cell line, and most likely also operates via an LPS-TLR4 mediated signaling pathway (14). Because the TLR-4 and IL-1 receptor contain shared cytoplasmic downstream signaling constituents, a tolerance to IL- $1 \beta$ activation was also observed in this cell line. More recently, Otte et al. (27) have shown cross tolerance to LPS and LTA in other intestinal cell lines (Colo 205, SW480, T84) mediated via TLR-4 and TLR-2 receptors respectively. In these studies they also showed a partial cross-tolerance to IL- $1 \beta$ but no effect on TNF- $\alpha$ activity. Of importance in all cases, cross-tolerance appears to be mediated via a functionally active TLR-family member complex and this may significantly inhibit the secretion of several pro-inflammatory cytokines such as TNF $\alpha$, IL-6 and IL-8.

IL-8 is known to play a central role in the initiation and maintenance of intestinal inflammatory and immune responses. The proinflammatory cytokine-induced IL-8 production requires activation of various kinases, which leads to $\mathrm{I} \kappa \mathrm{B} \alpha$ degradation and $\mathrm{NF} \kappa \mathrm{B}$ activation. The present work demonstrates a broad-spanning LPS-induced tolerance in human IEC that specifically diminishes IL- 8 secretion in response to agonists such as IL- $1 \beta, \mathrm{TNF} \alpha$ and PMA. This tolerance is caused by a down-regulation of IL- 8 gene expression in IEC exposed to LPS and does not appear to involve substantial posttranscriptional regulation such as aberrant secretion and intracellular degradation of this chemokine.

Contrary to macrophages, LPS-induced tolerance of IL-8 secretion in human IEC does not appear to be mediated via the TLR-4/MD-2 signaling complex as little or no functional TLR-4 and MD-2 is expressed in human IEC. Novel LPSmediated signaling pathways imparted by commensal gut flora 
may therefore exist in human IEC that protects intestinal barrier-function from locally secreted IL-8 (28). Distinct signaling pathways not associated with TLR-4 activation may therefore be involved in the induction of LPS-mediated IL-8 tolerance in human IEC. It is conceivable that LPS activates alternative extracellular receptor signaling pathways in IEC that function independently of TLR-4/MD-2 activation. For example, CFTR has recently been shown to act as a LPS pattern recognition molecule that activates $\mathrm{NF} \kappa \mathrm{B}$ translocation in human epithelial cells (29). Another example includes TLR-independent activation of G-protein coupled plateletactivating factor receptor in epithelial cells by LTA (30). Nuclear $\mathrm{NF} \kappa \mathrm{B}$ translocation is subsequently activated via disintegrin and metalloproteinase (ADAM10) cleavage of proheparin binding epidermal growth factor and trans-activation of the epidermal growth factor receptor. Further work is required to establish whether this tolerance is established via a distinct extracellular receptor, or whether internalized LPS may suppress IL-8 responses via activation of intracellular NOD pathways (31).

Several mechanisms have been implicated in the induction of LPS-mediated tolerance. These include diminished surface receptor expression or an increased engagement of the TLR4/MD-2 signaling complex, and diminished expression of downstream signaling mediators such as IRAK-1, I $\kappa \mathrm{B} \alpha$, $\mathrm{I} \kappa \mathrm{B} \beta, \mathrm{I} \kappa \mathrm{B} \epsilon, \mathrm{I} \kappa \mathrm{B} \xi, \mathrm{c}-\mathrm{jun} \mathrm{N}$-terminal kinase activity $(9-14,23-$ 27). Immunoblot analysis form our study indicates that LPSpretreatment induces a decrease in the degradation of $\mathrm{I} \kappa \mathrm{B} \alpha$, leading to the alteration in $\mathrm{NF} \kappa \mathrm{B}$ activation, contributing to the observed LPS-induced tolerance of IL-8 response.

It has also been shown that cellular differentiation influences the cytokine responsiveness of human IEC (18). Cytodifferentiation of HT29 cells inhibits IL- $1 \beta$-mediated NF $\kappa$ B activation and IL- 8 gene expression by impairing I $\kappa$ B kinase and c-Jun $\mathrm{N}$-terminal kinase activities in differentiated methotrexate-treated cells (18). A similar suppression was not observed for TNF- $\alpha$ and PMA activated cells, indicating that IL-1 $\beta$ signaling alone was altered by cellular differentiation. These findings do not explain the suppression of IL- $1 \beta$ signaling described herein as the tolerance was also recorded following observed TNF- $\alpha$ and PMA stimulation. This broadspanning tolerance effectively excludes the possibility that chronic LPS exposure of IEC down-regulates specific extracellular receptors (e.g., IL-1 receptor) or intracellular signaling mediators (e.g., IRAK-1) that are common to all the activation pathways. Quantitative real-time rtPCR analysis of the DPPIV gene expression demonstrated that LPS incubation of IEC did not induce cellular differentiation in IEC, excluding cellular differentiation as a mechanism for this tolerance.

In summary, our study demonstrates that exposure of human-derived IEC to LPS results in the induction of a broadspanning tolerance to IL- $1 \beta$, TNF- $\alpha$ and PMA activated IL- 8 response. However, LPS exposure does not alter other proinflammatory signaling cascades in IEC, such as IL-6 secretion and hepoxilin A3-induced neutrophil transepithelial migration in response to invasive bacterial pathogen, such as Salmonella typhimurium (22). These results, therefore, suggest that human intestinal commensal bacteria may impart a novel form of hyporesponsiveness by IEC to locally-acting cytokines that might otherwise promote IL-8 secretion, intestinal inflammation and cell death.

Acknowledgments. The authors thank Dr. B. Cherayil for helpful discussion and critical reviewing of this manuscript and Dr A. Keates for providing IL-8 promoter constructs.

\section{REFERENCES}

1. Fusunyan RD, Quinn JJ, Ohno Y, MacDermott RP, Sanderson IR 1998 Butyrate enhances interleukin (IL)-8 secretion by intestinal epithelial cells in response to IL-1beta and lipopolysaccharide. Pediatr Res 43:84-90

2. Naik S, Kelly EJ, Meijer L, Pettersson S, Sanderson IR 2001 Absence of Toll-like receptor 4 explains endotoxin hyporesponsiveness in human intestinal epithelium. J Pediatr Gastroenterol Nutr 32:449-453

3. Abreu MT, Vora P, Faure E, Thomas LS, Arnold ET, Arditi M 2001 Decreased expression of Toll-like receptor-4 and MD-2 correlates with intestinal epithelial cell protection against dysregulated proinflammatory gene expression in response to bacterial lipopolysaccharide. J Immunol 167:1609-1616

4. Medzhitov R 2001 Toll-like receptors and innate immunity. Nature Rev Immunol 1:135-145

5. Claud EC, Savidge T, Walker WA 2003 Modulation of human intestinal epithelial cell IL-8 secretion by human milk factors. Pediatr Res 53:419-425

6. Quaroni A, Beaulieu JF 1997 Cell dynamics and differentiation of conditionally immortalized human intestinal epithelial cells. Gastroenterology 113:1198-1213

7. McCormick BA, Colgan SP, Delp-Archer C, Miller SI, Madara JL 1993 Salmonella typhimurium attachment to human intestinal epithelial monolayers: transcellular signaling to subepithelial neutrophils. J Cell Biol 123:895-907

8. Zhao D, Keates AC, Kuhnt-Moore S, Moyers MP, Kelly CP, Pothoulakis C 2001 Signal transduction pathways mediating neurotensin-stimulated interleukin- 8 expression in human colonocytes. J Biol Chem 276:44464-44471

9. Medvedev AE, Kopydlowski KM, Vogel SN 2000 Inhibition of lipopolysaccharideinduced signal transduction in endotoxin-tolerized mouse macrophages: dysregulation of cytokine, chemokine, and toll-Like receptor 2 and 4 gene expression. J Immunol 164:5564-5574

10. Sato S, Nomura F, Kawai T, Takeuchi O, Muhlradt PF, Takeda K, Akira S 2000 Synergy and cross-tolerance between toll-like receptor (TLR) 2- and TLR-4 mediated signaling pathways. J Immunol 165:7096-7101

11. Lehner MD, Morath S, Michelsen KS, Schumann RR, Hartung T 2001 Induction of cross-tolerance by lipopolysaccharide and highly purified lipoteichoic acid via different Toll-like receptors independent of paracrine mediators. J Immunol 166:5161-5167

12. Wang JH, Doyle M, Manning BJ, Di WuQ, Blankson S, Redmond HP 2002 Induction of bacterial lipoprotein tolerance is associated with suppression of toll-like receptor 2 expression. J Biol Chem 277:36068-36075

13. Jacinto R, Hartung T, McCall C, Li L 2002 Lipopolysaccharide- and lipoteichoic acid-induced tolerance and cross-tolerance: distinct alterations in IL-1 receptorassociated kinase. J Immunol 168:6136-6141

14. Hornef MW, Frisan T, Vandewalle A, Normark S, Richter-Dahlfors A 2002 Tolllike receptor 4 resides in the Golgi apparatus and colocalizes with internalized lipopolysaccharide in intestinal epithelial cells. J Exp Med 195:559-570

15. Cario E, Rosenberg IM, Brandwein SL, Beck PL, Reinecker HC, Podolsky DK 2000 Lipopolysaccharide activates distinct signaling pathways in intestinal epithelial cell lines expressing Toll-like receptors. J Immunol 164:966-972

16. Cario E, Podolsky DK 2000 Differential alteration in intestinal epithelial cell expression of toll-like receptor 3 (TLR3) and TLR4 in inflammatory bowel disease. Infect Immun 68:7010-7017

17. Cario E, Brown D, McKee M, Lynch-Devaney K, Gerken G, Podolsky DK 2002 Commensal-associated molecular patterns induce selective toll-like receptortrafficking from apical membrane to cytoplasmic compartments in polarized intestinal epithelium. Am J Pathol 160:165-173

18. Bocker U, Schottelius A, Watson JM, Holt L, Licato LL, Brenner DA, Sartor RB, Jobin C 2000 Cellular differentiation causes a selective down-regulation of interleukin (IL)- $1 \beta$-mediated $\mathrm{NF} \kappa \mathrm{B}$ activation and IL- 8 gene expression in intestinal epithelial cells. J Biol Chem 275:12207-12213

19. Nanthakumar NN, Fusunyan RD, Sanderson I, Walker WA 2000 Inflammation in the developing human intestine: a possible pathophysiologic contribution to necrotizing enterocolitis. Proc Natl Acad Sci 97:6043-6048

20. Fusunyan RD, Nanthakumar NN, Baldeon ME, Walker WA 2001 Evidence for an innate immune response in the immature human intestine: toll-Like receptors on fetal enterocytes. Pediatr Res 49:589-593

21. Lipkin M 1987 Proliferation and differentiation of normal and diseased gastrointestinal cells. In: Johnson LR (ed) Physiology of the Gastrointestinal Tract, Raven Press, New York, pp 255-284.

22. Mrsny RJ, Gewirtz AT, Siccardi D, Savidge T, Hurley BP, Madara JL, McCormick BA 2004 Identification of hepoxilin A3 in inflammatory events: a required role in neutrophil migration across intestinal epithelia. Proc Natl Acad Sci 101:7421-7426 
23. Mizel SB, Snipes JA 2002 Gram-negative flagellin-induced self-tolerance is associated with a block in interleukin-1 receptor-associated kinase release from toll-like receptor 5. J Biol Chem 277:22414-22420

24. Ferlito M, Romanenko OG, Ashton S, Squadrito F, Halushka PV, Cook JA 2001 Effect of cross-tolerance between endotoxin and TNF-alpha or IL-1beta on cellular signaling and mediator production. J Leukoc Biol 70:821-829

25. Dobrovolskaia MA, Medvedev AE, Thomas KE, Cuesta N, Toshchakov V, Ren T, Cody MJ, Michalek SM, Rice NR, Vogel SN 2003 Induction of in vitro reprogramming by Toll-like receptor (TLR) 2 and TLR4 agonists in murine macrophages: effects of TLR "homotolerance" versus "heterotolerance" on NF-kappa B signaling pathways components. J Immunol 170:508-519

26. Medvedev AE, Henneke P, Schromm A, Lien E, Ingalls R, Fenton MJ, Golenbock DT, Vogel SN 2001 Induction of tolerance to lipopolysaccharide and mycobacterial components in Chinese hamster ovary/CD14 cells is not affected by overexpression of Toll-like Receptors 2 or 4. J. Immunol 167:2257-2267
27. Otte JM, Cario E, Podolsky DK 2004 Mechanisms of cross hyporesponsiveness to Toll-like receptor bacterial ligands in intestinal epithelial cells. Gastroenteorlogy 126:1054-1070

28. Yan F, Polk DB 2002 Probiotic bacterium prevents cytokine-induced apoptosis in intestinal epithelial cells. J Biol Chem 277:50959-50965

29. Schroeder TH, Lee MM, Yacono PW, Cannon CL, Gerceker AA, Golan DE, Pier GB 2002 CFTR is a pattern recognition molecule that extracts Pseudomonas aeruginosa LPS from the outer membrane into epithelial cells and activates $\mathrm{NF} \kappa \mathrm{B}$ translocation. Proc Natl Acad Sci 99:6907-6912

30. Lemjabbar H, Basbaum C 2002 Platlet-activating factor receptor and ADAM10 mediate responses to Staphylococcus aureus in epithelial cells. Nat Med 8:41-46

31. Girardin SE, Boneca IG, Carneiro LA, Antignac A, Jehanno M, Viala J, Tedin K, Taha MK, Labigne A, Zathringer U, Coyle AJ, DiStefano PS, Bertin J, Sansonetti PJ, Philpott DJ 2003 Nod1 detects a unique muropeptide from gram-negative bacterial peptidoglycan. Science 300:1584-1587 